\title{
Diabetes Mellitus an Emerging Ice-Burg
}

\author{
Rajendra Nath* \\ Department of Pharmacology \& Therapeutics, King George's Medical University, India
}

Submission: October 20, 2016; Published: November 01, 2016

*Corresponding author: Rajendra Nath, Department of Pharmacology \& Therapeutics, King George's Medical University, India, Email: rajendra.nath79@gmail.com

\section{Editorial}

Diabetes, a noncommunicable life style disease, has acquired a status of epidemic since last two -three decades surpassing all the barriors of race, ethnicity, poverty and affluency. Diabetes mellitus has been recognized as a growing worldwide epidemic by WHO and many other healths's advocacy group. The WHO has estimated that diabetes will be one of the world leading causes of death and disability with next quarter century. The statistics are alarming; 30 million people were diagnosed with diabetes worldwide in 1985, by 1995 the number had risen to 135 million, and at the current rate there will be some 300 million by the year 2025 as predicted by the WHO.

Diabetes mellitus is a metabolic disorder characterized by hyperglycemia, abnormal lipid, and protein metabolism along with specific long-term complication affecting the retina, kidney, and nervous system. Diabetes mellitus has a significant impact on the health, quality of life and life expectancy of patients as well as on the health care system. According to American Diabetes Association (ADA), total economic cost of diabetes was estimated to be $\$ 98$ billion which includes $\$ 44$ billion in direct medical and treatment costs, and $\$ 54$ billion in indirect costs related to disability and mortality. The prevalence of all forms of diabetes is estimated to be $2 \%-3 \%$ of the world's population, with the number of diabetics increasing by $4 \%-5 \%$ per annum. Prevalence of DM type- 2 is increasing by leaps \& bounds in Asian developing countries. India having the leading position.

Microvascular complication account for significant morbidity \& mortality.

\section{Major trials like DCCT (Diabetes Control and Complications Trial) and UKPDS}

(United Kingdom Prospective Diabetes Study) have shown the effect of sustained tight blood glucose control in preventing or postponing microvascular complications. It has become vitally important for a family physician / medical officers / Consultants to have a thorough knowledge of patho-physiology, diagnosis and management of Diabetes. Increasing awareness in print and electronic media and self-monitoring of blood glucose have also sensitized the common man, and large section of population is being recognized as prediabetes which are potential targeted population for diabetes control to prevent the new onset of diabetes or delay its full blown clinical picture.

The present generation of diabetologist, endocrinologist, and experts involved in alternative treatment options e.g. Yoga, Dietary changes, Medicinal herbs \& other dietary micronutrients, have now too many new drugs and methods (holistic approach) which restore physiology of Insulin secretion. Understanding of glucose metabolism, lipid abnormalities, gene polymorphism, preservation of beta cell and its regeneration with stem cells \& most importantly life style changes is now the challenge of the day. Many such efforts have now started e.g., The World Congress on Clinical Trials in Diabetes (WCTD2016), is going on and we expect some important result.

I am thankful to the Chief Editor of Current Research in Diabetes and Metabolism Journal, who has given me chance to express my views on one of the most frequent searched disease on this planet. I hope this Journal which deals with research involved in fundamental principles of diabetes practice and new emerging research trends and trials on diabetes, especially the coming issue will be an asset to Physicians, Researchers, Scientists, which are involved in day to day practice, inventing the new drugs and mechanisms and their application, which can prevent \& treat the Diabetes mellitus as a worldwide goal. 
Your next submission with JuniperPublishers will reach you the below assets

- Quality Editorial service

- Swift Peer Review

- Reprints availability

- E-prints Service

- Manuscript Podcast for convenient understanding

- Global attainment for your research

- Manuscript accessibility in different formats

(Pdf, E-pub, Full Text, Audio)

- Unceasing customer service

Track the below URL for one-step submission

http://juniperpublishers.com/online-submission.php 